Sapna. dkk. Pengaruh Pemberian Ekstrak Kulit Pisang Kepok (Musa acuminata)

\title{
PENGARUH PEMBERIAN EKSTRAK KULIT PISANG KEPOK (Musa acuminata) TERHADAP PENURUNAN KADAR MALONDIALDEHID (MDA) PARU MENCIT JANTAN (Mus musculus) YANG DIPAPAR ASAP ROKOK
}

\section{THE EFFECT OF KEPOK BANANA PEEL (Musa acuminata) EXTRACT IN LUNG MALONDIALDEHYDE (MDA) LEVEL IN MALE MICE (Mus Musculus) EXPOSED BY CIGARETTE SMOKE}

\author{
Sapna Kurnia Dewi 1), Widya Paramitha Lokapirnasari 2), Dewa Ketut Meles 2), \\ Imam Mustofa 2), Maslichah Mafruchati 2), Iwan Sahrial Hamid 2) \\ 1) Mahasiswa 2) Dosen \\ Fakultas Kedokteran Hewan Universitas Airlangga \\ Kampus C UNAIR, Jl. Mulyorejo-Surabaya 60115 \\ Telp. 031-5992785, Fax. 031-5993015 \\ Email: jbmvunair@gmail.com
}

\begin{abstract}
This research aimed to determine the effect of kepok banana peel extract (Musa acuminata) given by per oral in decreasing levels of malondialdehyde (MDA) in lung of male mice (Mus musculus) which was exposed to cigarette smoke. The 24 experimental male mice were divided into 6 groups. The therapy was given for 14 days, all mice were sacrificed and lung MDA level were examined with thiobarbituricacid (TBA) methods. The result of the data analysis test using one-way ANOVA (Analysis of Variance) showed that there were significant differences between the group of animals that exposed to cigarette smoke $(\bar{x}=840.50 \pm 186.47 \mathrm{nmol} / \mathrm{g})$ and the group of animals that were given with extract of kepok banana peel $56 \mathrm{mg} / \mathrm{kg}$ bw $(\bar{x}=6471.25 \pm 69.25$ $\mathrm{nmol} / \mathrm{g}$ ). Besides that, there was an significant difference between the groups of animals that were exposed cigarette smoke ( $\bar{x}=840.50 \pm 186.47 \mathrm{nmol} / \mathrm{g})$ with the group of animals that were given with vitamin C $260 \mathrm{mg} / \mathrm{kg}$ bw $(\bar{x}=555.25 \pm 61.16 \mathrm{nmol} / \mathrm{g})$. It could be concluded that extract of kepok banana peel and vitamin $C$ could decrease MDA levels in lung of male mice which was exposed cigarette smoke. The increased therapy dose gave affect in lowering levels of malondialdehyde in lung.
\end{abstract}

Key words: Musa acuminata, malondialdehyde (MDA), lung, vitamin C

\section{PENDAHULUAN}

Berdasarkan riset Atlas Tobacco, jumlah perokok di Indonesia pada 2016 telah mencapai lebih dari 90 juta jiwa. Riset Kesehatan Dasar (Rikesdas, 2013), sebesar 85\% rumah tangga di Indonesia terpapar asap rokok. Tingginya angka perokok berdampak pada semakin tingginya resiko penyakit. Tidak hanya pada perokok aktif namun perokok pasif juga beresiko terserang penyakit akibat paparan asap rokok. Resiko paparan asap rokok diantaranya adalah terjangkit penyakit kardiovascular, kanker, tumor, dan penyakit paru obstruksi kronis. Hal ini dapat berdampak pada hewan peliharaan yang dipelihara di lingkungan perokok (Hari dkk., 2010).

Merokok dapat menyebabkan kelainan fungsi paru obstruktif, pneumonia, influenza dan penyakit infeksi pernafasan akut (Eisner, 2008). Selain perokok aktif, perokok pasif yang menghirup asap rokok juga memiliki resiko gangguan kesehatan mencapai 30\% (Barber, 2008) 
Kematian pada laki-laki yang mengidap tuberculosis paru $50 \%$ disebabkan karena merokok dan 3,25\% dari perokok berkembang menjadi penderita tuberculosis (Sarwani dan Nurlela, 2012). Rokok merupakan salah satu faktor pemicu terjadinya kanker paru-paru (Gupta, 2001).

Asap rokok mengandung radikal bebas dalam jumlah tinggi. Dalam satu kali hisapan rokok diperkirakan terdapat sebanyak 1.014 molekul radikal bebas yang masuk ke dalam tubuh (Yueniwati dan Ali, 2014). Kandungan berbahaya dari asap rokok diantaranya adalah nikotin, karbon monoksida, akrolein, hidrokarbon polisiklik dan Nnitrosamin (Moritsugu, 2006). Kandungan Nikotin pada rokok memiliki efek berbahaya dan menyebabkan kecanduan (Fitria dkk., 2013). Tiga zat kimia paling berbahya pada rokok adalah tar, nikotin, dan karbon monoksida (Nurrurahmah, 2014).

Merokok dapat menyebabkan timbunan radikal bebas di tubuh. Ketidak seimbangan antara antioksidan dan radikal bebas pada tubuh menghasilkan stress oksidatif (Ardhie, 2011). Radikal bebas yang berlebihan dan kurangnya antioksidan dapat memicu terbentuknya Reactive Oxygen Species (ROS). Reactive Oxygen Species (ROS) di dalam tubuh cenderung bereaksi dengan jaringan sehingga menimbulkan reaksi berantai yang dapat menyebabkan kerusakan jaringan (Agarwal et al., 2005).

Suatu proses dimana radikal bebas mengambil elektron-elektron lipid pada membran sel dan menyebabkan kerusakan sel disebut perioksidasi lipid (Kusuma, 2010). Produk sekunder hasil metabolit dari perioksidasi lipid adalah Malondialdehid (MDA). Malondialdehid (MDA) digunakan sebagai indikator atau tanda terjadinya stress oksidatif, MDA terbentuk dari peroksidasi lipid pada membran sel, yaitu reaksi antara radikal bebas (radikal hidroksi) dengan Poly Unsaturated Fatty Acid (PUFA) (Sirait dkk., 2016)

Kerusakan oksidatif dapat dicegah dan diatasi dengan pemberian antioksidan. Antioksidan pemutus rantai meliputi vitamin C, vitamin E dan betakaroten (Chevion et al., 2003). Kombinasi vitamin C dan vitamin E tidak menurunkan kadar MDA plasma, namun menghambat peningkatan kadar MDA plasma (Yasin dkk., 2015). Pemberian vitamin $\mathrm{C}$ yang ditambahkan dengan antioksidan lain seperti mineral seng, magnesium dan antioksidan non enzimatik golongan flavonoid menunjukkan hasil yang signifikan menurunkan kadar MDA (Winarsi, 2011).

Antioksidan dapat berasal dari dalam dan luar tubuh yang didapatkan dari bahan makanan alami dari tanaman, kandungan flavonoid dapat ditemukan pada tanaman (Sirait dkk., 2016). Salah satu tanaman yang banyak tumbuh di Indonesia adalah pisang. Pisang banyak dikonsumsi oleh masyarakat dari berbagai kalangan, namun limbah kulit pisang belum banyak dimanfaatkan.

Kulit pisang berpotensi sebagai sumber antioksidan. Kulit pisang kepok mengandung flavonoid, alkaloid, tannin/polifenol.saponin dan triterpenoid (Lumowa dan Bardin, 2017) Ekstrak kulit pisang mengandung antioksidan cukup tinggi dengan aktivitas 95,14\% (Supriyanti dkk., 2015)

Kandungan flavonoid pada kulit pisang kepok bekerja dengan cara bereaksi dengan lipid mencegah terjadinya perioksidasi lipid dengan cara meredam radikal peroksil, mengakhiri reaksi radikal, memadamkan super anion superoksida dan melindungi PUFA (Poly Unsaturated Fatty Acid). Fenolik merupakan antioksidan yang berfungsi memutus reaksi berantai dan sebgai antioksidan preventif (Widowati dkk., 2005) 
Berdasarkan uraian di atas, perlu dilakukan penelitian lebih lanjut manfaat kulit pisang kepok sebagai sumber antioksidan alami untuk menurunkan kadar malondialdehide MDA.

\section{MATERI DAN METODE PENELITIAN}

\section{Bahan dan Sampel Penelitian}

Bahan yang digunakan pada penelitian ini adalah mencit jantan (Mus musculus), kulit pisang kepok, ethanol 96\% teknis, CMC-Na (Carboxymethyl Cellulose $\mathrm{Na}$ ) 1\% Ex Finland, rokok kretek djarum 76, $\mathrm{NaCl}$ Fisiologis 0,9\% Otsuka, serbuk kayu, pakan dan minum mencit, dan TBA assay.

\section{Metode Penelitian}

Mencit jantan (Mus musculus) sebanyak 24 ekor yang dibagi enam perlakuan masing-masing empat ekor. Adaptasi dilakukan selama 7 hari bertujuan agar hewan coba tidak mengalami stres. Pada hari ke-8 perlakuan dimulai dengan pemaparan asap rokok sebanyak 1 batang perhari selama 14 hari. Ekstrak etanol kulit pisang kepok dengan 3 dosis berbeda untuk P1, P2 dan P3, untuk $\mathrm{K}+$ tidak diberi ekstrak setelah pemaparan sedangkan K- tidak diberi pemaparan asap rokok maupun ekstrak kulit pisang kepok. KO merupakan kontrol obat yang diberikan vitamin C. Dosis ekstrak etanol daun kulit pisang kepok yang digunakan yaitu $14 \mathrm{mg} / \mathrm{kgBB}, 28$ $\mathrm{mg} / \mathrm{kgBB}, 56 \mathrm{mg} / \mathrm{kgBB}$. Dosis vitamin $C$ yang diberikan yaitu $0,3 \mathrm{mg} / 25 \mathrm{gBB}$ per hari.

Penelitian ini dibagi menjadi enam perlakuan dalam satu perlakuan terdapat empat ulangan, dosis berbeda untuk P1, P2, P3. Mencit diberi makan dan minum secara ad libitum. Perlakuan dilakukan selama 28 hari dan pada hari ke-29 semua mencit dikorbankan dengan cara cervical dislocation untuk diambil organ paru.

\section{Tahap Pengambilan Sampel}

Pada hari ke-36 semua mencit dikorbankan dengan cara cervical dislocation untuk diambil organ paru. Pengukuran kadar MDA menggunakan organ paru. Selanjutnya organ paru yang telah dikoleksi ditimbang $\pm 250 \mathrm{mg}$ yang selanjutnya dilakukan pemeriksaan kadar MDA paru menggunakan TBA assay (thiobarbituric acid) (Rael et al., 2004).

\section{Pengukuran Kadar MDA}

Pada tahap ini dilakukan pengukuran kadar MDA yang dapat diukur dengan TBA assay (thiobarbituric acid). TBA assay merupakan metode yang paling sering digunakan untuk mendeteksi kadar MDA. Reaksi antara MDA dan TBA akan membentuk kromogen warna merah yang dapat diukur absorbansinya dengan spektofotometer dengan panjang gelombang $532 \mathrm{~nm}$ (Rael et al., 2004).

\section{Analisis Data}

Data kadar MDA didistribusikan dalam tabel menggunakan uji kolmogorov Smirnov dan penilaian data menggunakan uji levene. Distribusi data normal dan varians homogen apabila nilai $p>0,05$. Jika distribusi data normal maka dilanjutkan dengan menggunakan uji One-Way Anova jika terdapat perbedaan nyataPost-Hoc Duncan (AlArif, 2018). 


\section{HASIL DAN PEMBAHASAN}

Tabel 1. Rerata dan simpangan baku kadar MDA paru menit jantan (mus musculus) yag dipapar asap rokok selama 14 hari dan diberikan ekstrak kulit pisang kepok (Musa acuminata) selama 14 hari.

\begin{tabular}{|c|c|c|}
\hline No & Perlakuan & Rerata \pm Simpang baku (nmol/g) \\
\hline 1 & $\mathrm{~K}(-)$ & $503,25^{\mathrm{a}} \pm 83,60$ \\
\hline 2 & $\mathrm{~K}(+)$ & $840,50^{\mathrm{c}} \pm 186,47$ \\
\hline 3 & $\mathrm{KO}$ & $555,25^{\mathrm{a}} \pm 61,16$ \\
\hline 4 & P1 & $725,00^{\mathrm{bc}} \pm 101,03$ \\
\hline 5 & P2 & $718,50^{\mathrm{bc}} \pm 47,73$ \\
\hline 6 & P3 & $647,25^{\mathrm{ab}} \pm 69,95$ \\
\hline
\end{tabular}

a, ab, bc, c Superskrip yang berbeda dalam kolom yang sama menunjukan perbedaan yang nyata $(\mathrm{p}<0.05)$

Berdasarkan hasil penelitian, terdapat perbedaan nyata antara kelompok kontrol negatif yang diberi pakan standar saja dengan kelompok kontrol positif yang dipapar asap rokok. Kelompok kontrol negatif dengan kelompok yang diberi terapi vitamin $\mathrm{C}$ tidak terdapat perbedaan yang nyata. Kelompok kontrol negatif dengan perlakuan ekstak kulit pisang kepok dosis $14 \mathrm{mg} / \mathrm{kgBB}$ dan dosis 28 $\mathrm{mg} / \mathrm{kgBB}$ terdapat perbedaan yang nyata. Kelompok kontrol negatif dengan perlakuan ekstrak kulit pisang kepok dosis $56 \mathrm{mg} / \mathrm{kgBB}$ tidak terdapat perbedaan yang nyata. Kelompok kontrol positif yang dipapar asap rokok saja tidak terdapat perbedaan yang nyata dengan kelompok perlakuan ekstrak kulit pisang kepok dosis 14 $\mathrm{mg} / \mathrm{kgBB}$ dan dosis $28 \mathrm{mg} / \mathrm{kgBB}$. Kelompok kontrol positif yang dipapar asap rokok saja terdapat perbedaan yang nyata dengan kelompok perlakuan ekstak kulit pisang kepok dosis 56 $\mathrm{mg} / \mathrm{kgBB}$. Kelompok kontrol positif yang dipapar asap rokok saja terdapat perbedaan yang nyata dengan kelompok kontrol obat yang diberikan vitamin C dosis $260 \mathrm{mg} / \mathrm{kgBB}$.
Kelompok kontrol negatif yang memiliki rerata kadar MDA yang rendah karena tidak mendapat perlakuan selain diberi pakan standar saja. kelompok K- mendapatkan hasil terendah dan berbeda nyata terhadap kelompok P1, P2 dan $\mathrm{K}+$, sedangkan Ktidak berbeda terhadap kelompok $\mathrm{KO}$ dan P3.

Kelompok kontrol positif memiliki rerata kadar MDA yang paling tinggi dibanding dengan kelompok perlakuan yang lain. Peningkatan rerata kadar MDA yang terjadi pada kelompok hewan coba dipapar asap rokok saja disebabkan oleh paparan asap rokok merupakan salah satu sumber radikal bebas. Jika tubuh sering terpapar oleh asap rokok maka radikal bebas yang terakumulasi dalam tubuh akan semakin bertambah yang selanjutnya dapat meyebabkan stress oksidatif yang ditandai dengan peningkatan kadar MDA dalam tubuh (Komar, 2010). Radikal bebas seperti anion superoksida $\left(\mathrm{O}_{2-}\right)$, radikal hidroksil $(\mathrm{OH}-)$, hydrogen perioksida $\left(\mathrm{H}_{2} \mathrm{O}_{2}\right)$, radikal nitrit oksida (NO), dan peroksinitrit (ONOO-) diproduksi melalui proses enzimatik dan non enzimatik. Pada stress oksidatif 
radikal bebas oksigen yang terbentuk tentu berlebihan begitu juga dengan $\mathrm{H}_{2} \mathrm{O}_{2}$ yang terbentuk banyak, sehingga sistem proteksi tubuh seperti enzim katalase dan glutation peroksidase tidak dapat lagi menetralkan semua radikal bebas oksigen yang terbentuk (Ayala et al., 2014).

Selanjutnya jika $\mathrm{H}_{2} \mathrm{O}_{2}$ bereaksi dengan dengan $\mathrm{Fe}^{+2}$ dan $\mathrm{Cu}^{+2}$ maka terbentuklah radikal bebas hidroksil melalui reaksi Fenton dan Haber-Weiss. Radikal hidroksil adalah spesies yang sangat reaktif. Membran sel terdiri dari banyak komponen penting yaitu fosfolipid, glikolipid, (keduanya mengandung asam lemak tak jenuh) dan kolesterol. Terjadi reaksi antara radikal bebas (radikal hidroksi) dengan Poly Unsaturated Fatty Acid (PUFA). Asam lemak tak jenuh ini sangat peka terhadap radikal hidroksil. Asam lemak tak jenuh meliputi asam oleat, asam linoleat, asam linolenat dan asam arakidonat (Ayala et al., 2014).

Kemampuan radikal hidroksil ini akan membentuk reaksi rantai dengan satu atom hidrogen dari membran sel dan terbentuk peroksida lipid. Kelanjutan dari reaksi ini adalah terputusnya rantai asam lemak menjadi senyawa aldehid yang memiliki daya perusak yang tinggi terhadap sel-sel tubuh antara lain malondialdehid, 4hidroksinenal, etana dan pentana. Demikian pula dengan DNA dan protein juga mengalami kerusakan (Ayala, et al., 2014). MDA digunakan sebagai indikator kadar perioksidasi lipid dan adanya kerusakan peroksidatif (Agarwal et al., 2008).

Terapi vitamin $C$ pada kelompok kontrol obat berbeda nyata dengan kelompok perlakuan P1 dan P2 dengan terapi ekstrak kulit pisang kepok. Kerusakan oksidatif dapat dicegah dan diatasi dengan pemberian antioksidan. Antioksidan pemutus rantai meliputi vitamin C, vitamin $\mathrm{E}$ dan betakaroten (Chevion et al., 2003). Pemberian vitamin $\mathrm{C}$ yang ditambahkan dengan antioksidan lain seperti mineral seng, magnesium dan antioksidan non enzimatik golongan flavonoid menunjukkan hasil yang signifikan menurunkan kadar MDA (Winarsi, 2011).

Rerata kadar MDA pada kelompok perlakuan P3 menunjukkan perbedaan yang signifikan pada pemberian terapi ekstrak kulit pisang kepok dengan dosis $56 \mathrm{mg} / \mathrm{kgBB}$. Rerata kadar MDA paru dari kelompok perlakuan P3 ini berbeda nyata dengan kelompok mencit yang dipapar asap rokok $(\mathrm{K}+)$. Hal ini dikarenakan aktivitas antioksidan pada kulit pisang mencapai $94,25 \%$ pada konsentrasi 125 $\mu \mathrm{g} / \mathrm{ml}$ (Deborah \& Gemayangsura, 2015). Ekstrak kulit pisang kepok mengandung senyawa turunan polifenol yang dapat bekerja sebagai antioksidan yaitu flavonoid. Senyawa ini mempunyai aktivitas antioksidan yang tinggi sehingga dapat bekerja sebagai antioksidan secara langsung maupun tidak langsung. Flavonoid mendonorkan ion hidrogen sehingga mampu menetralisir efek toksik dari radikal bebas, peran ini yang dimaksud sebagai antioksidan langsung. Flavonoid juga berperan sebagai antioksidan tidak langsung dengan cara meningkatkan ekspresi gen antioksidan endogen. Sehingga terjadi peningkatan ekspresi gen yang berperan dalam sintesis enzim antioksidan endogen seperti superoksida dismutase (Widowati dkk., 2005). Penelitian Yanping et al. (2005) dan Rasyid et al. (2012) menyatakan bahwa flavonoid mampu menurunkan kadar MDA dengan signifikan

Senyawa fenolik yang terkandung dalam kulit pisang kepok memiliki minimal satu gugus hidroksil yang menempel di cincin aromatic. Adanya cicin aromatic mempengaruhi kestabilan ikatan atom oksigen dengan hydrogen, sehingga senyawa fenolik dapat bertindak sebagai donor atom hydrogen kepada radikal bebas. Senyawa fenolik 
bertindak sebagai penampung yang baik terhadap $\mathrm{O}_{2-}$ dan $\mathrm{OH}-$, yang melindungi lipid membrane terhadap reaksi oksidasi yang merusak, sehingga pembentukan malondialdehid dapat dicegah (Samak dkk., 2009).

\section{KESIMPULAN}

Berdasarkan penelitian yang telah dilakukan, dapat disimpulkan bahwa ekstrak kulit pisang kepok dengan dosis $56 \mathrm{mg} / \mathrm{kgBB}$ yang diberikan selama 14 hari pada mencit jantan yang dipapar asap rokok selama 14 hari mampu menurunkan kadar MDA paru. Pemberian peningkatan dosis terapi memberikan pengaruh pada penurunan kadar MDA paru.

\section{DAFTAR PUSTAKA}

Al-arif, MA. 2018. Rancangan Percobaan. Surabaya: Lutfansyah Mediatama.

Agarwal A, Makker K, and Sharma R. 2008. Clinical relevance of oxidative stress in male factor infertility: an update, American Journal of Reproductiction Immunologi, 59:2-11.

Agarwal A and Prabakara SA. 2005. Mechanism, measurement, and prevention of oxidative stress in male reproductive physiology, indian Journal of Experimental Biology. 43: 963-974.

Ayala A, Munoz MF, Arguelles S. 2014. Lipid Peroxidation: Production, Metabolism, and Signaling Mechanisms of Malondialdehyde and 4-Hydroxy-2-Nonenal. Oxidative Medicine and Cellular Longevity 1-31

Badade ZG and Samant PM. 2011. Role of Oxidative Stress in Male Infertility. Journal Biomed Sci and Res. 3(2) 385-391.
Barber S, Adioetomo SM, Ahsan A, \& Setyonaluri, D. 2008. Tembakau di Indonesia. Laporan Penelitian. Lembaga Demografi Fakultas Ekonomi Universitas Indonesia. Jakarta.

Baretto, RTM. 2010. Nitric oxide as a maker of smoking abstinence. Institute of Medical Science, University of Toronto. Canada 8788.

Britton J, and Edwards F. 2007. Tobacco Smoking, harm reduction, and nicotine product regulation. Lancet 317 (9610) :441-445.

Chevion S, Moran DS, Heled Y, Shani Y, Regev G, Abbou B, Bernstein E, Stadtman ER, Epstein Y. 2003. Plasma antioxidant status and cell injury after severe physical exercise. Proc. Natl. Acad. Sci. USA 100:5119-5123

Deborah dan Gemayangsura. 2015. Khasiat Kulit Pisang Kepok (Musa acuminata) sebagai Agen Preventif Ulkus Gaster. Majority. 4 (8): 17-22.

Eisner, M. 2008. Biology and Mechanisms for Tobaccoattributable Respiratory Diseases, including TB, Bacterial Pnemonia and other Respiratory Diseases. The International Journal of Tuberculosis and Lung Disease.12.

Fitria, Triandhini, RINKR, Mangimbulude, JC, Karwur, FF. 2013. Merokok dan Oksidasi DNA. Sains Medika, 5(2).

Gupta, C. 2001. The public Health Impact Tobacco. Current Science: 81(5) 
Hari AE, Roni N, Agung WT. 2010. Paparan Asap Dalam Rumah, Hewan Peliharaan, Lingkungan Tempat Tinggal, dan Sosial Ekonomi Dengan Kejadian Asma Bronkial pada Anak. Berita Kedokteran Masyarakat. 3(26): 125-131

Holguin, F. 2013. Oxidative stress in airway disease. Ann Am Thorax Soc. 10:150.

Lumowa SVT, Bardin S. 2018.Uji Fitokimia Kulit Pisang Kepok (Musa paradisiaca L.) Bahan Alam Sebagai Pestisida Nabati Berpotensi Menekan Serangan Serangga Hama Tanaman Umur Pendek.Jurnal Sains dan Kesehatan 1(9): 465-469.

Mohod K, Ninghot A, Ansari AK, Garg N. 2014. Circulating Lipid Peroxide and Antioxsidant Status in Cigarette Smokers: An Oxidaive Damage Phenmena. IJHSR 4(5): 261.

Moritsugu, KP. 2006. The Report of the Surgeon General: The Health Consequences of Involuntary Exposure to Tobacco Smoke. American J. Prev. Med. 32(6): 542543.

Moselhy HF, Reid RG, Yousef S, Boyke SP. 2009. A Spesific, Accurate and Sensitif Measurement Total Plasma Malondialdehide by HPLC. Journal of Lipid Research.

Nuttal SL, Routledge HC, Manney S. 2002. Circulating and Exhaled Markers of Nitric Oxide and Antioxidant Activity after Smooking. Circulation.106:145.
Nurrurahmah, 2014. Pengaruh Rokok Terhadap Kesehatan Dan Pembentukan Karakter Manusia. Prosiding Seminar Nasional 1(1).

Onasanwo SA, Emikpe BO, Ajah AA, Elufioye TO. 2013. Anti Ulcer and Ulcer Healing Potentials of Musa sapientum Peel Extract in The laboratory Rodents, Pharmacognosy Research 5: 173179.

Patel BP, Rawal UM. 2008. Tobacco, antioxidant enzymes, oxidative stress, and genstic susceptibility in oral cancer. Am.J. Clin. Oncol, 31: 454-459.

Prameswari, YN. 2014. Pengaruh Pemberian Dosis Bertingkat Madu terhadap Gamabaran Mikroskopik Paru pada Mencit Strain Balb/c Jantan yang diberi Paparan Asap Rokok. Jurnal Media Medika Muda.

Rael LT, Thomas GW, Craun ML, Curtis CG, Bar-Or R, Bar-Or D. 2004. Lipid Peroxidation and the Thiobarbituric Acid Assay: Standardization of the Assay When Using Saturated and Unsaturated Fatty Acids. Journal of Biochemistry and Molecular Biology, 37(6):749-452.

Rasyid HN, Ismiarto YD, Prasetia R.2012. The efficacy of flavonoid antioxidant from chocolate bean extract: prevention of myocyte demage cause by reperfusion injury in predominantly anaerobic sports. Malaysian Orthopedic Journal. 6(3): $3-6$. 
Samak, G, Shenoy RP, Manjunantha SM, and Vinayak, KS. 2009. Superoxide and Hidroxyl Radical Scavenging Actions of Botanical Extracts of Wagatea spicata. Food Chemistry. 115(2):631-634

Sarwani, Dwi dan Nurlela, S. 2012. Merokok dan Tuberculosis Paru. Kesehatan Masyarakat Universitas Jenderal Soedirman.

Sirait RC, Tjahjono DKK, Setiawati AN. 2016. Pengaruh Pemberian Ekstrak Jintan Hitam (Nigella Sativa) Terhadap Kadar Mda Serum Tikus Sprague Dawley Setelah Diberikan Paparan Asap Rokok. Jurnal Kedokteran Diponegoro 5(4).

Supriyanti F, Maria T. 2015. Pemanfaatan Ekstrak Kulit Pisang Kepok (Musa Bluggoe) Sebagai Sumber Antioksidan pada Produksi Tahu. Makalah Pendamping Biokimia, Departemen Pendidikan Kimia, FPMIPA Bandung.

Tirtosastro S, dan Murdiyati AS. 2010. Kandungan Kimia Tembakau dan Rokok. Buletin Tanaman Tembakau, Serat \& Minyak Industri 2(1).

Tonnesen P, Carozzi L, Fagerstrom KO, Gratziou C, Jimenez-Ruiz C, Nardini S, Viegi G, Lazzaro C, Campell IA, Dagli E, West R. 2007. Smoking cessation in patients with respiratory diseases: a high priority, integral component of therapy. Eur Respir J. 29:390-417
Wardiyah, K.2016. Pengaruh Paparan Asap Rokok dengan Biofilter berbahan Kurma (Phoenix dactylifera L.) Zaitun (Olea europanea) dan Delima (Punica granatum linn) terhadap Gambaran Histopatologi Hati, Paru-Paru, Dan Viskositas Darah Mencit (Mus musculus) [skripsi]. Fakultas Sains dan Teknologi. Universitas Islam Negeri Maulana Malik Ibrahim.

Widayati, E. 2018.Oxidasi Biologi, Radikal Bebas, dan Antioxidant. Bagian Kimia-Biokimia FK Unissula Semarang.

Widowati W, Safitri R., Rumumpuk R, dan Siahaan M. 2005. Penapisan aktivitas superoksida dismutase pada bagian tanaman. JKM, 5(1): 33-47.

Winarsi H. 2011. Antioksidan Alami dan Radikal Bebas.Yogyakarta. Kanisus. 7-50

Yanping Z, Yanhua L, Dongzhi W.2005 Hypercholesterolemic effects of a flavonoid -rich extract of Hyper perforatum L. in rat fed a cholesterol -rich diet. J Agric Food Chem. 53: 2462 -2466.

Yasin KY, Kartasurya MI, RMD Kisdjamiatun RA. 2015. Pengaruh Kombinasi Vitamin C dan Vitamin E terhadap Kadar Malondialdehid plasma pasien diabetes mellitus tipe 2. 4(1):1-8 